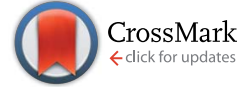

Cite this: J. Mater. Chem. A, 2015, 3, 6177

Received 4th December 2014 Accepted 10th February 2015

DOI: 10.1039/c4ta06643j

www.rsc.org/MaterialsA

\section{Ultrathin oxide shell coating of metal nanoparticles using ionic liquid/metal sputtering $\dagger$}

\author{
Tsukasa Torimoto, ${ }^{\text {*a }}$ Yasuhiro Ohta, ${ }^{a}$ Kazuki Enokida, ${ }^{a}$ Daisuke Sugioka, ${ }^{a}$ \\ Tatsuya Kameyama, ${ }^{a}$ Takahisa Yamamoto, ${ }^{a}$ Tamaki Shibayama, ${ }^{\text {b Kazuki Yoshii, }}$ \\ Tetsuya Tsudac and Susumu Kuwabata*c
}

\begin{abstract}
The surface coating of metal nanoparticles resulting into core-shell structures is expected to improve the physicochemical properties of the nanoparticle cores without changing their size and shape. Here, we developed a novel strategy to coat Au, AuPd or Pt catalyst cores having average sizes smaller than 2.5 $\mathrm{nm}$, which were pre-synthesized in ionic liquids by corresponding metal sputtering, with an extremely thin $\mathrm{In}_{2} \mathrm{O}_{3}$ layer (ca. $<1.5 \mathrm{~nm}$ ) by sputter deposition of indium in a room-temperature ionic liquid. The metal cores of Au or AuPd in core-shell particles exhibited superior stability against heat treatments or during electrocatalytic reactions compared to the corresponding bare metal particles. $\mathrm{The} \ln _{2} \mathrm{O}_{3}$ shell coating considerably enhanced the durability of electrocatalytically active Pt particles (1.2 nm). This sequential metal sputter deposition of different metals in ionic liquids will considerably contribute to the exploitation of key nanostructured components for next-generation energy-conversion systems.
\end{abstract}

\section{Introduction}

Metal nanoparticles exhibit tunable catalytic properties depending on the particle size, shape, and their chemical composition. $^{\mathbf{1 - 4}}$ Many strategies have been reported to improve the catalytic activities of metal nanoparticles and their tolerance to deactivation for fabrication of highperformance devices, such as fuel cells ${ }^{5,6}$ and automotive exhaust gas purification systems. ${ }^{7,8}$ The formation of coreshell structures by particle coating with shell layers has proven advantageous for modifying the catalytic properties of nanoparticles without affecting their dimensions. ${ }^{\mathbf{9 - 1 5}}$ So far, many strategies have been developed to prepare core-shellstructured particles. Sol-gel methods have been intensively investigated for coating noble metal catalyst particle surfaces with metal oxides such as $\mathrm{SiO}_{2}$ and $\mathrm{TiO}_{2} \cdot{ }^{\mathbf{1 1 , 1 4 , 1 6 , 1 7}}$ The layer-bylayer approach has enabled the deposition of polyelectrolytes, such as ionic polymers or inorganic nanosheets as shell materials on surface-charged particles. ${ }^{18-22}$ The partial oxidation of metal particle surfaces has produced metal oxide shell layers on metal cores. ${ }^{23,24}$ However, coating a metal particle with an extremely thin layer remains difficult

${ }^{a}$ Graduate School of Engineering, Nagoya University, Furo-cho, Chikusa-ku, Nagoya 464-8603, Japan. E-mail: torimoto@apchem.nagoya-u.ac.jp

${ }^{b}$ Center for Advanced Research of Energy Conversion Materials, Hokkaido University, Sapporo 060-8628, Japan

'Graduate School of Engineering, Osaka University, 2-1 Yamada-oka, Suita, Osaka 565-0871, Japan

$\dagger$ Electronic supplementary information (ESI) available: TEM images, XPS spectra, and cyclic voltammograms of metal@In ${ }_{2} \mathrm{O}_{3}$ particles. See DOI: 10.1039/c4ta06643j by conventional techniques, especially for particles smaller than ca. $3 \mathrm{~nm}$ exhibiting high catalytic activity. This is related to inter-particle coalescence and/or thick shell formation on the surface, which sometimes induce considerable deterioration of catalytic activity of core particles.

Room-temperature ionic liquids (RTILs) exhibited unique features compared with those of water or conventional organic solutions and they have attracted much attention as media for preparation of inorganic nanoparticles. ${ }^{25-33}$ Metal sputter deposition in RTILs under reduced pressure ${ }^{31,32,34-42}$ has recently produced noble metal nanoparticles, such as $\mathrm{Au},{ }^{34} \mathrm{Ag},{ }^{35} \mathrm{Pd},{ }^{36}$ and $\mathrm{Pt},{ }^{39}$ without additional stabilizing agents. This RTIL/metal sputtering technique has also enabled the preparation of alloy nanoparticles, such as AuAg, ${ }^{35} \mathrm{AuPd},{ }^{41}$ and AuPt, ${ }^{40}$ by simultaneous sputtering of two different metal plates. The resulting nanoparticles displaying particle size of several nanometers in diameter did not present any stabilizing agent adsorption on their surface and were expected to show high catalytic activities. However, the presence of the bare surface on the nanoparticles suggested that the particles exhibited a strong tendency to coalesce into larger structures, which decreases catalytic activity. Therefore, a nanoparticle stabilization technique is required for their long-term catalyst life.

In this study, we prepared novel core-shell particles via RTIL/metal sputtering, in which noble metals, such as $\mathrm{Au}$, AuPd, and Pt, and a base metal of In were sequentially deposited in RTILs. The obtained particles consisted of a small noble metal core ( $c a$. $<2.5 \mathrm{~nm}$ ) surrounded by an ultrathin indium oxide shell (ca. $<1.5 \mathrm{~nm})$ and then the thermal stability of noble metal cores in core-shell particles 
was much more enhanced than that of bare particles. The $\mathrm{In}_{2} \mathrm{O}_{3}$-coated AuPd nanoparticles acted as electrocatalysts for ethanol oxidation and oxygen reduction. Furthermore the durability of electrocatalytically active $\mathrm{Pt}$ particles was improved by coating with the $\operatorname{In}_{2} \mathrm{O}_{3}$ shell.

\section{Experimental}

\section{Preparation of core-shell-structured $\mathrm{Au} @ \operatorname{In}_{2} \mathrm{O}_{3}$ and AuPd@In ${ }_{2} \mathrm{O}_{3}$ particles}

Fig. 1 shows the schematic illustration of preparation of noble metal (M) core- $\mathrm{In}_{2} \mathrm{O}_{3}$ shell nanoparticles (M@ $\mathrm{In}_{2} \mathrm{O}_{3}$ ). First, noble metals, such as an Au or an AuPd alloy, were sputterdeposited on RTILs under reduced Ar pressure using the corresponding metal targets to prepare uniform metal nanoparticle dispersions in RTILs. Next, the noble metal target plate was replaced with an In target plate and this second metal was sputter-deposited onto the thus-obtained metal-particledispersed RTILs.

Gold nanoparticles were sputter-deposited in 1-ethyl-3methylimidazolium tetrafluoroborate (EMI-BF4) used as an RTIL by a previously-reported method ${ }^{34,35,41}$ with a slight modification. A portion of EMI-BF4 $\left(0.60 \mathrm{~cm}^{3}\right)$, that was vacuumdried for $3 \mathrm{~h}$ at $150{ }^{\circ} \mathrm{C}$ before use, was spread on a glass plate $\left(10 \mathrm{~cm}^{2}\right)$ horizontally set in a sputter coater (Sanyu Electron Co. Ltd., SC-701HMCII). The plate was located $25 \mathrm{~mm}$ from an $\mathrm{Au}$ target (diameter: $49 \mathrm{~mm}$ ). The sputter deposition of Au in EMIBF4 was conducted for $10 \mathrm{~min}$ at $10 \mathrm{~mA}$ under an argon pressure of $c a$. 2.0 $\mathrm{Pa}$ at room temperature. The thus-obtained $\mathrm{Au}$
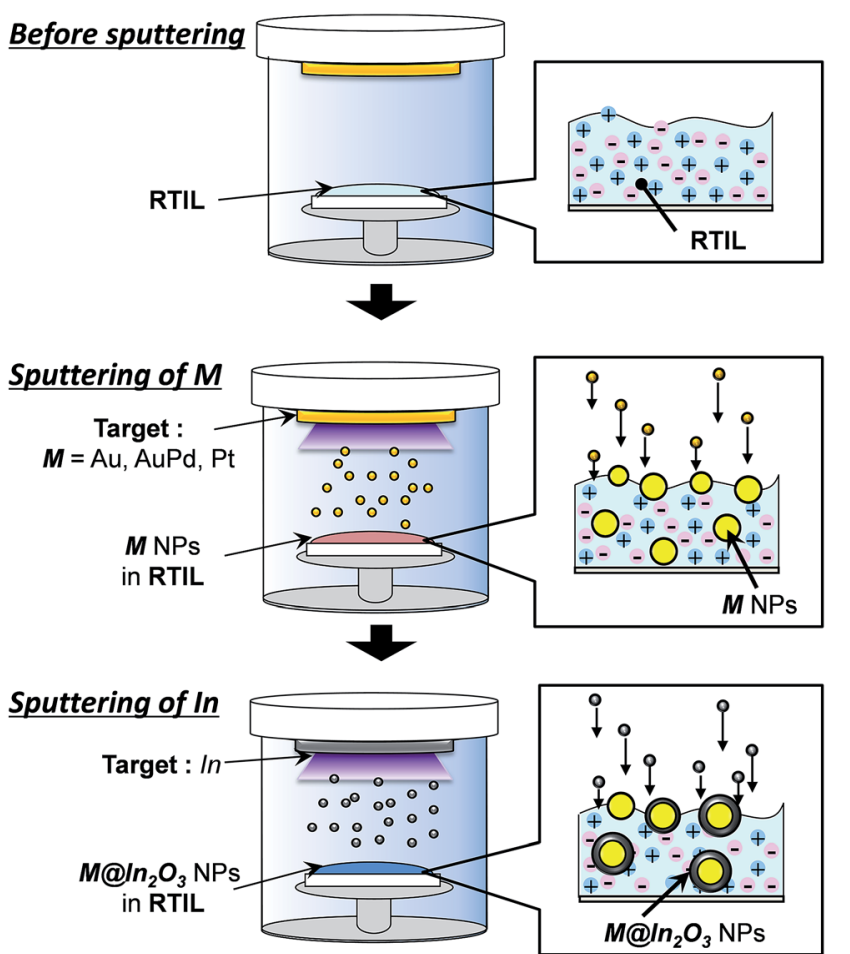

Fig. 1 Schematic for the preparation procedure of noble metal (M) core- $\ln _{2} \mathrm{O}_{3}$ shell nanoparticles ( $M\left(\mathrm{ln}_{2} \mathrm{O}_{3}, \mathrm{M}=\mathrm{Au}\right.$, AuPd, or Pt). nanoparticles had the average size of $2.2 \mathrm{~nm}$, in which the concentration of particles amounted to $19 \mu \mathrm{mol}$ (particle) $\mathrm{dm}^{-3}$, measured using X-ray florescence spectroscopy. On the other hand, for the preparation of AuPd alloy nanoparticles, ${ }^{34,35,41}$ the binary Au-Pd metal target was prepared by radially and alternately arranging $\mathrm{Au}$ (99.99\% in purity) and Pd plates (99.99\%), which each had a fan-like shape with a central angle of $30^{\circ}$. This target was used for the simultaneous sputter deposition instead of a pure Au target. The area fraction of Au plates in targets, $f_{\mathrm{Au}}$ $\left(=A_{\mathrm{Au}} /\left(A_{\mathrm{Au}}+A_{\mathrm{Pd}}\right)\right)$, equalled 0.50 , where $A_{\mathrm{Au}}$ and $A_{\mathrm{Pd}}$ were the total surface areas of Au and Pd plates, respectively. After the simultaneous sputter deposition of Au and Pd under the same sputtering condition, the resulting EMI-BF4 contained AuPd particles (average size: $2.0 \mathrm{~nm}$ ) at a particle concentration of $26 \mu \mathrm{mol}$ (particle) $\mathrm{dm}^{-3}$.

The subsequent In sputter deposition on thus-obtained EMIBF4 solutions containing noble metal particles was carried out by replacing a noble metal target plate by an In metal one. The In sputter deposition on EMI-BF4 containing Au particles lasted for $30 \mathrm{~min}$ at $10 \mathrm{~mA}$ under an argon pressure of $c a$. 2.0 $\mathrm{Pa}$ at room temperature to obtain $\mathrm{In}_{2} \mathrm{O}_{3}$-coated $\mathrm{Au}$ nanoparticles ( $\mathrm{Au} @ \mathrm{In}_{2} \mathrm{O}_{3}$ ). For the preparation of $\mathrm{AuPd} @ \mathrm{In}_{2} \mathrm{O}_{3}$, the In sputtering time for AuPd nanoparticle EMI-BF4 dispersions was varied from 10 to $30 \mathrm{~min}$ under the same sputtering condition. Thus-obtained EMI-BF4 solutions containing $\mathrm{Au} @ \mathrm{In}_{2} \mathrm{O}_{3}$ or AuPd@ $\operatorname{In}_{2} \mathrm{O}_{3}$ were heat-treated at various temperatures for 30 min in air with vigorous stirring if necessary.

The shape and size distribution of the obtained particles was examined using a Hitachi H7650 transmission electron microscope (TEM) with an acceleration voltage at $100 \mathrm{kV}$. Samples for TEM measurements were prepared by dropping a particle-containing EMI-BF4 solution onto a carbon-coated copper grid, which was washed with acetonitrile and then dried under reduced pressure. High resolution images of high-angle-annular-dark-field scanning transmission microscopy (HAADF-STEM) were obtained by Cs-corrected HR-STEM (ARM-200F, JEOL Co. Ltd.) with an acceleration voltage at $200 \mathrm{kV}$. The energy-dispersive X-ray spectroscopy (EDX) analysis was simultaneously carried out during TEM measurements using an electron probe of $c a .1 \mathrm{~nm}$ in diameter.

\section{Electrochemical measurements of the electrocatalytic activity} of AuPd@In $\mathrm{O}_{3}$-modified HOPG electrodes

Synthesized nanoparticles were immobilized by heat treatment as reported previously. ${ }^{41}$ An aliquot $\left(20 \mathrm{~mm}^{3}\right)$ of EMI-BF4 solution containing bare AuPd nanoparticles or AuPd@ $\operatorname{In}_{2} \mathrm{O}_{3}$ (the concentration of AuPd particles: $26 \mu \mathrm{mol}$ (particle) $\mathrm{dm}^{-3}$ ) was spread on highly-oriented pyrolytic graphite (HOPG) $\left(1.4 \mathrm{~cm}^{2}\right)$ before heat treatment at 100 or $200{ }^{\circ} \mathrm{C}$ for 30 min under vacuum. These modified HOPG electrodes were washed several times with acetonitrile to remove unattached nanoparticles and dried at room temperature. The surface morphology of the nanoparticle films on HOPG was examined in air by an atomic force microscope (AFM) (Veeco Instruments Inc., NanoScope IIIa). 
The electrocatalytic activities of nanoparticle-modified HOPG electrodes were assessed using an electrochemical analyser (BAS Instruments Inc., ALS model 701C). Electrochemical measurements were conducted using a three-electrode electrochemical cell, in which the AuPd-immobilized HOPG electrode acted as the working electrode, a Pt wire as the counter electrode, and a reversible hydrogen electrode (RHE) as the reference electrode. The electrolyte used for oxygen reduction reaction (ORR) was an $\mathrm{O}_{2}$-saturated $0.50 \mathrm{~mol} \mathrm{dm}^{-3} \mathrm{KOH}$ aqueous solution, while the one for ethanol oxidation consisted of a degassed aqueous solution containing $0.50 \mathrm{~mol} \mathrm{dm}^{-3}$ ethanol and $0.50 \mathrm{~mol} \mathrm{dm}{ }^{-3} \mathrm{KOH}$. Cyclic voltammograms were obtained at a sweep rate of $100 \mathrm{mV} \mathrm{s}^{-1}$. The apparent area of the working electrode was set to $0.16 \mathrm{~cm}^{2}$ using an O-ring. The current density was calculated by dividing the obtained current by the electrochemically active surface area (ECSA) of AuPd particles obtained by the literature procedure. ${ }^{43}$

\section{Preparation of Pt@In $\mathrm{In}_{2} \mathrm{O}_{3}$-loaded carbon particles and their} durability for polymer electrolyte fuel cells

Platinum nanoparticles measuring $1.2 \mathrm{~nm}$ in diameter were sputter-deposited in 1-butyl-3-methylimidazolium tetrafluoroborate $\left(B M I-B_{4}\right)\left(0.40 \mathrm{~cm}^{3}\right)$, spread on a glass plate $\left(6.3 \mathrm{~cm}^{2}\right)$, for $15 \mathrm{~min}$ at $40 \mathrm{~mA}$ under an argon pressure of $c a$. 9.5 Pa. The $\operatorname{In}_{2} \mathrm{O}_{3}$ surface coating was carried out by the subsequent In metal sputtering for $2 \mathrm{~min}$ at $10 \mathrm{~mA}$ under an argon pressure of $c a$. 2.0 Pa. $\mathrm{Pt} @ \mathrm{In}_{2} \mathrm{O}_{3}$ particles were immobilized on carbon black particles (VULCAN XC-72) (Pt@ $\left.\operatorname{In}_{2} \mathrm{O}_{3} / \mathrm{C}\right)$ for a Pt content of $c a .5 \mathrm{wt} \%$ by a previously-reported method with heat treatment at $150{ }^{\circ} \mathrm{C} .{ }^{39}$ For comparison, bare Pt particles (size: $1.2 \mathrm{~nm}$ ) were similarly immobilized on carbon black particles (Pt/C, ca. $5 \mathrm{wt} \%-\mathrm{Pt})$. After mixing the resulting powders $(1.0 \mathrm{mg})$ with $0.05 \mathrm{wt} \%$ Nafion ${ }^{\circledR}$ solution $\left(0.50 \mathrm{~cm}^{3}\right)$, catalyst powders (Pt@ $\mathrm{In}_{2} \mathrm{O}_{3} / \mathrm{C}$ or Pt/C, $10 \mu \mathrm{g}$ ) were immobilized on a glassy carbon rotating disk electrode $\left(0.20 \mathrm{~cm}^{2}\right)$. The durability test of Pt catalysts was performed according to the test protocol recommended by the Fuel Cell Commercialization Conference of Japan (FCCJ). ${ }^{44,45}$ The step-like potential cycling between 0.6 and $1.0 \mathrm{~V}$ vs. RHE was carried out in $0.1 \mathrm{~mol} \mathrm{dm}^{-3} \mathrm{HClO}_{4}$ aqueous solution degassed by $\mathrm{N}_{2}$ bubbling at a room temperature, in which the holding period was $3 \mathrm{~s}$ at each potential application. The ECSA of Pt particles was measured in $0.10 \mathrm{~mol} \mathrm{dm}^{-3} \mathrm{HClO}_{4}$ aqueous solution saturated with $\mathrm{N}_{2}$ after at least every 500 cycles of the potential step. The electrocatalytic activity for ORR was evaluated by measuring hydrodynamic voltammograms for ORR

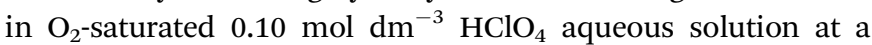
rotational speed of $1600 \mathrm{rpm}$ with a potential scan rate of $10 \mathrm{mV} \mathrm{s}^{-1}$ after every 1000 cycles of the potential step.

\section{Results and discussion}

Surface coating of noble metal nanoparticles with thin indium oxide shells

Particles of the noble metal (M) core- $\mathrm{In}_{2} \mathrm{O}_{3}$ shell nanostructure ( $\mathrm{M} @ \mathrm{In}_{2} \mathrm{O}_{3}$ ) were prepared by the procedure shown in Fig. 1. Fig. 2a-c show representative TEM images of
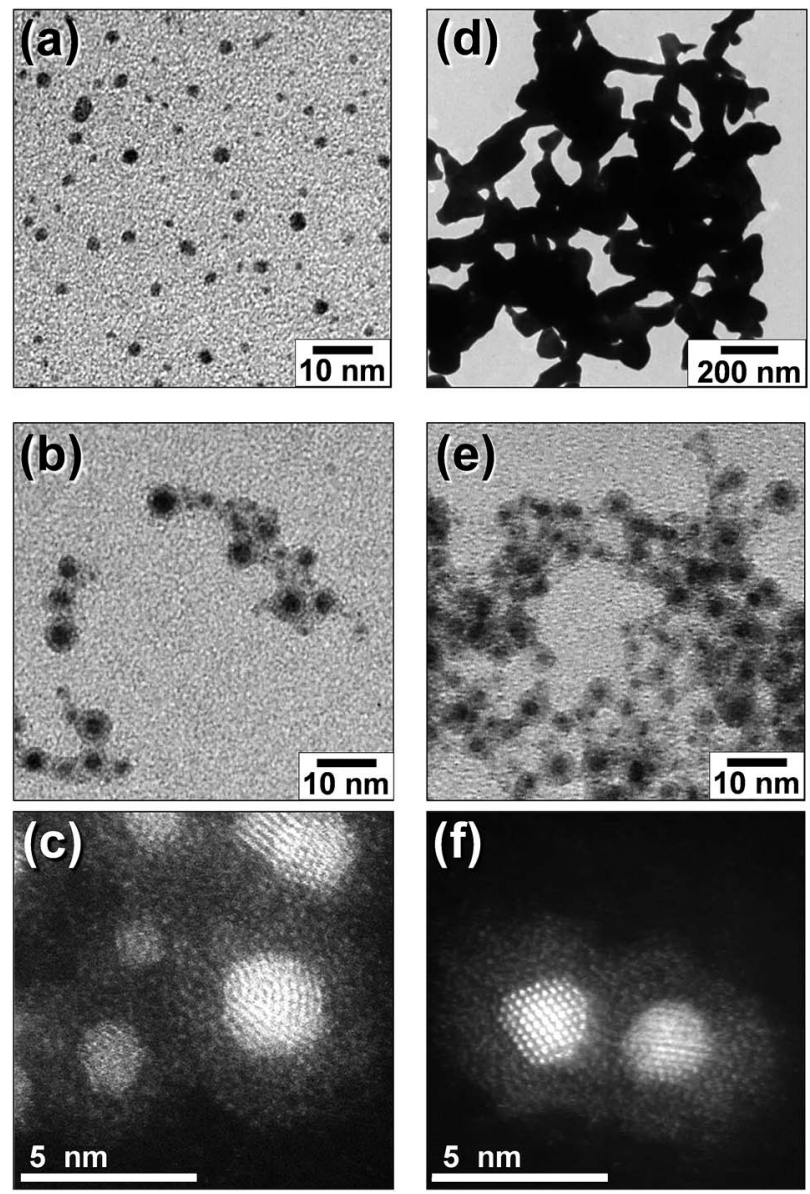

Fig. 2 Representative TEM images of sputter-deposited Au particles (a) and Aual $n_{2} \mathrm{O}_{3}$ (b and c) in EMI-BF4 and those of heat-treated particles of bare $\mathrm{Au}(\mathrm{d})$ and $\mathrm{AuC} \mathrm{ln}_{2} \mathrm{O}_{3}$ (e and f). The heat treatment of the solutions was conducted at $250{ }^{\circ} \mathrm{C}$ for $1 \mathrm{~h}$. Panels $\mathrm{c}$ and $\mathrm{f}$ show high-magnification HAADF-STEM images of particles in panels $b$ and $e$, respectively.

nanoparticles formed in an EMI-BF4 solution at individual steps. The simple sputter deposition of Au produced spherical $2.2 \mathrm{~nm}$-diameter $\mathrm{Au}$ nanoparticles in the solution without particle aggregation as shown in Fig. 2a. Subsequent In sputtering covered individual Au nanoparticle surfaces with thin layers without changing the core size $(c a .2 .2 \mathrm{~nm}$, Fig. 2b). Whole core-shell particles displayed an average diameter of $c a .4 .4 \mathrm{~nm}$ by TEM. The shell thickness was assumed to be equal to half the difference between the $\mathrm{Au}$ core (ca. $2.2 \mathrm{~nm}$ ) and $\mathrm{Au@} \mathrm{In}_{2} \mathrm{O}_{3}$ particle diameters, which amounted to $c a$. $1.1 \mathrm{~nm}$. X-ray fluorescence spectroscopy showed that the $\mathrm{Au}$ : In molar ratio amounted to $1: 3.9$ in the thus-obtained EMI-BF4 dispersion, consistent with that of $\mathrm{Au} @ \mathrm{In}_{2} \mathrm{O}_{3}$ particles comprising a $2.2 \mathrm{~nm}$-diameter Au-core surrounded by a $c a$. $1.1 \mathrm{~nm}$-thick $\mathrm{In}_{2} \mathrm{O}_{3}$ shell.

A high-angle-annular-dark-field scanning transmission microscopy (HAADF-STEM) image of the core-shell particles at high magnification is shown in Fig. 2c. Cores exhibited clear lattice fringes with a $0.24 \mathrm{~nm}$ interplanar spacing assignable to $\mathrm{Au}$ (111) lattice planes. The shell layers displaying a thickness ranging between 1 and $1.5 \mathrm{~nm}$ exhibited an amorphous 
structure and completely covered the individual cores. The energy-dispersive X-ray spectroscopy (EDX) analysis simultaneously obtained by TEM measurements (electron probe diameter, $c a .1 \mathrm{~nm}$ ) revealed that the shell layer predominantly contained In as a metallic element, while the core consisted of $\mathrm{Au}$. It has been previously reported ${ }^{46}$ that the sputter deposition of the In metal in EMI-BF4 produced In metal core- $\mathrm{In}_{2} \mathrm{O}_{3}$ shell particles (In@ $\operatorname{In}_{2} \mathrm{O}_{3}$ ), in which the $4.6 \mathrm{~nm}$-diameter In metal core was covered by an amorphous $1.7 \mathrm{~nm}$-thick indium oxide shell. Thus the valence states of In in the $\mathrm{Au} @ \mathrm{In}_{2} \mathrm{O}_{3}$ particles were analysed using X-ray photoelectron spectroscopy (XPS) (Fig. S1 $\dagger$ ). The In $3 d_{5 / 2}$ and $3 d_{3 / 2}$ signals presented two sets of peaks. One set consisted of two small signals at binding energies of 444.1 and $451.7 \mathrm{eV}$, which agreed with $\mathrm{In} 3 \mathrm{~d}_{5 / 2}$ and $3 \mathrm{~d}_{3 / 2}$ signals for the $\operatorname{In}(0)$ metal observed at 443.49 and $451.18 \mathrm{eV},{ }^{47}$ respectively. The second set comprised two large signals at 446.0 and $453.6 \mathrm{eV}$ for In $3 \mathrm{~d}_{5 / 2}$ and $3 \mathrm{~d}_{3 / 2}$, respectively and was assigned to $\operatorname{In}(\mathrm{III})$ in $\operatorname{In}_{2} \mathrm{O}_{3}$, though the observed signals exhibited energies higher than those reported for $\operatorname{In}_{2} \mathrm{O}_{3}(444.5$ and $452.1 \mathrm{eV}$, respectively). ${ }^{48}$ This may stem from the strong adsorption of EMI-BF4 and/or the electronic interaction between the $\mathrm{Au}$ core and the $\operatorname{In}_{2} \mathrm{O}_{3}$ shell. Therefore, it was concluded that the sequential sputter deposition of $\mathrm{Au}$ and In produced Au core- $\operatorname{In}_{2} \mathrm{O}_{3}$ shell particles, in which the shell was composed of an ultrathin amorphous $\operatorname{In}_{2} \mathrm{O}_{3}$ layer. It is worth noting that the signal intensity ratio of $\operatorname{In}(\mathrm{III}): \operatorname{In}(0)$ in the XPS spectrum was ca. 1:0.12, suggesting that In(III) species predominantly contributed to the thermal stability of $\mathrm{Au}$ particle cores below-mentioned.

The order of this sequential deposition was critical to prepare noble metal core-metal oxide shell particles. The In@ $\operatorname{In}_{2} \mathrm{O}_{3}$ particles obtained by simple sputter deposition of the In metal onto pure EMI-BF4 displayed much larger diameters (ca. $14 \mathrm{~nm}$ ) than $\mathrm{Au} @ \mathrm{In}_{2} \mathrm{O}_{3}$ (4.4 nm, Fig. 2b). The following $\mathrm{Au}$ sputtering onto the EMI-BF4 solution containing $\operatorname{In} @ \operatorname{In}_{2} \mathrm{O}_{3}$ produced a simple mixture of $\operatorname{In} @ \mathrm{In}_{2} \mathrm{O}_{3}$ and bare $2.2 \mathrm{~nm}$ diameter Au particles (Fig. S2 $\dagger$ ) instead of Au-coated In@ $\mathrm{In}_{2} \mathrm{O}_{3}$. A mechanism may therefore be proposed for the $\mathrm{Au} @ \mathrm{In}_{2} \mathrm{O}_{3}$ formation (Fig. 3). Sputtered In species are injected into the $\mathrm{Au}$ particle-dispersed RTIL. Small Au particles act as nuclei for sputter-deposited In species in the RTIL, and then a thin In metal layer is predominantly deposited on the Au nanoparticle surface via heterogeneous nucleation in place of homogeneous
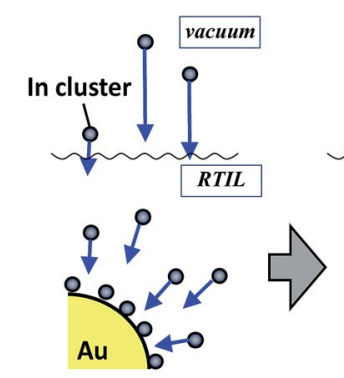
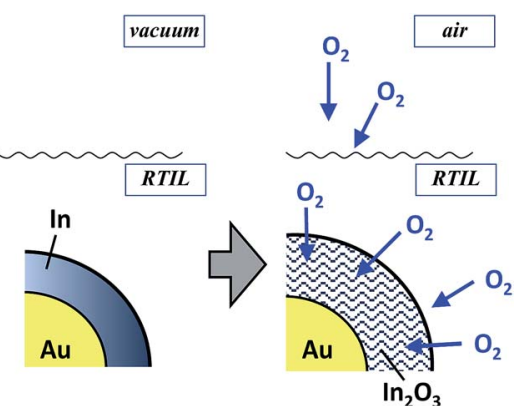

Fig. 3 Schematic for the formation of $\mathrm{Au@l} \mathrm{n}_{2} \mathrm{O}_{3}$ particles via oxidation of In metal sputter-deposited on Au nanoparticle cores. nucleation to produce large In metal particles. Subsequently, the In layer rapidly oxidized into a thin $\operatorname{In}_{2} \mathrm{O}_{3}$ shell by reactions with $\mathrm{H}_{2} \mathrm{O}$ or $\mathrm{O}_{2}$ molecules present in RTIL as dissolved impurities or incorporated upon air exposure.

The noble metal cores exhibited remarkably improved thermal stability despite their extremely thin $\operatorname{In}_{2} \mathrm{O}_{3}$ shells. The bare $2.2 \mathrm{~nm}$-diameter $\mathrm{Au}$ nanoparticles readily coalesced into larger particles $(\mathrm{ca} .>200 \mathrm{~nm})$ upon heat treatment at $250{ }^{\circ} \mathrm{C}$ (Fig. 2d). In contrast, $\mathrm{Au} @ \mathrm{In}_{2} \mathrm{O}_{3}$ maintained its core-shell structure even when heated in EMI-BF4 at $250{ }^{\circ} \mathrm{C}$ for $1 \mathrm{~h}$ in air (Fig. 2e). TEM images provided Au core diameters of 2.2 and 2.5 $\mathrm{nm}$ and $\mathrm{In}_{2} \mathrm{O}_{3}$ shell thicknesses of 1.1 and $1.6 \mathrm{~nm}$ before and after heat treatment, respectively, indicating that the $\mathrm{Au@} \mathrm{In}_{2} \mathrm{O}_{3}$ nanostructure remained almost unchanged. The high-resolution HAADF-STEM image (Fig. 2f) shows that, in heat-treated $\mathrm{Au} @ \mathrm{In}_{2} \mathrm{O}_{3}$, the Au core, exhibiting a lattice fringe corresponding to the $\mathrm{Au}$ (111) plane, remained completely covered with the amorphous $\operatorname{In}_{2} \mathrm{O}_{3}$ shell.

This sequential metal sputter deposition in ionic liquids enabled us to prepare core-shell particles incorporating different kinds of core metals. For example, the $\operatorname{In}_{2} \mathrm{O}_{3}$ shell coating was successfully carried out for Au, AuPd, AuPt, or Pt particles as a noble metal core. Furthermore, the shell thickness could be varied by controlling the In sputtering time. Fig. $4 \mathrm{a}-\mathrm{c}$ show HAADF-STEM images of AuPd@ $\operatorname{In}_{2} \mathrm{O}_{3}$ particles formed after different In sputtering times. The original spherical AuPd nanoparticle cores (Fig. 4a) were covered by a thin $\operatorname{In}_{2} \mathrm{O}_{3}$ layer after 10 (Fig. 4b) and $30 \mathrm{~min}$ of In sputter deposition (Fig. 4c). Average AuPd core sizes, $\operatorname{In}_{2} \mathrm{O}_{3}$ shell thicknesses, and overall AuPd@ $\mathrm{In}_{2} \mathrm{O}_{3}$ particle sizes were estimated from TEM
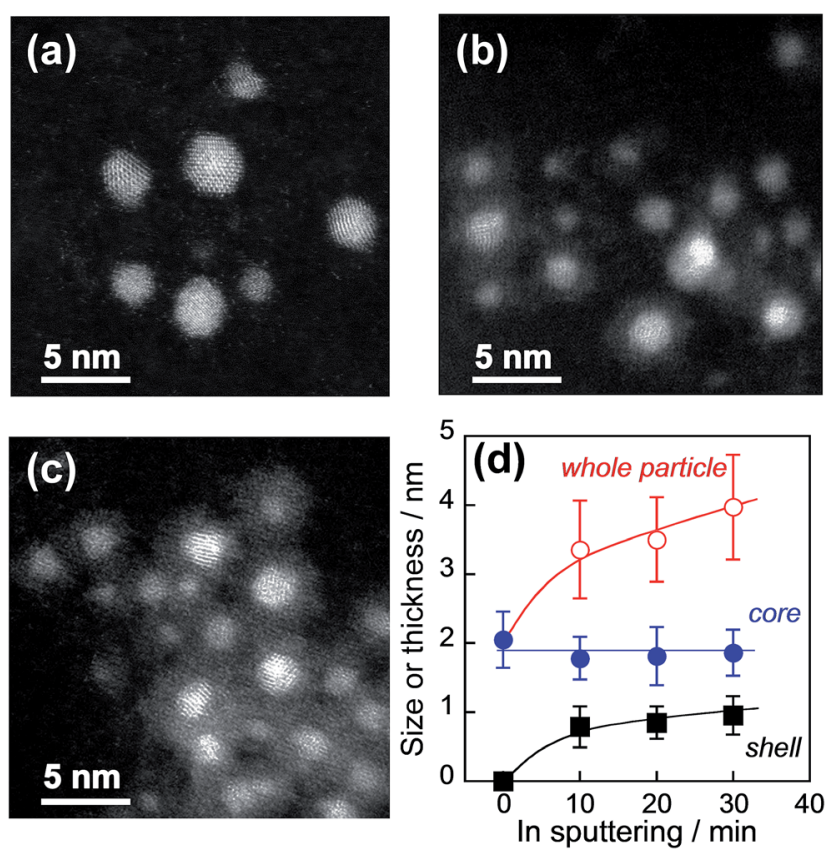

Fig. 4 Representative HAADF-STEM images of original AuPd particles (a) and AuPd@ $\ln _{2} \mathrm{O}_{3}$ particles formed after different In sputtering times (b and c). The In sputtering time amounted to 10 (b) and $30 \mathrm{~min}$ (c). (d) Overall AuPdal $n_{2} \mathrm{O}_{3}$ size, AuPd core sizes, and $\ln _{2} \mathrm{O}_{3}$ shell thicknesses as a function of In sputtering time. 
measurements and plotted in Fig. $4 \mathrm{~d}$ as a function of In sputtering time. The overall particle size increased from 2.0 to 4.0 $\mathrm{nm}$ when the sputtering time rose from 0 to $30 \mathrm{~min}$. The $\operatorname{In}_{2} \mathrm{O}_{3}$ shell thickness, which was assumed equal to half the difference between the AuPd core and overall particle average diameters, increased slightly from 0.79 to $0.95 \mathrm{~nm}$ with increasing In sputtering time. EDX analyses at the same time as the TEM observations gave an $\mathrm{Au}: \mathrm{Pd}$ molar ratio of $0.71: 0.29$ for the AuPd core in AuPd@ $\operatorname{In}_{2} \mathrm{O}_{3}$ obtained after In sputtering for 30 min, which was in good agreement with that of original bare AuPd particles $(0.70: 0.30)$. In addition, the shell predominantly contained $\mathrm{In}_{2} \mathrm{O}_{3}$.

The thermal stability of AuPd nanoparticles was also greatly improved by the surface coating with a thin $\operatorname{In}_{2} \mathrm{O}_{3}$ shell as expected. Fig. 5 shows the XRD patterns of original AuPd particles and AuPd@ $\operatorname{In}_{2} \mathrm{O}_{3}$ particles before and after heat treatment at various temperatures. As-prepared bare AuPd particles exhibited broad diffraction peaks due to their small crystallite size, and the diffraction angle of each peak was consistent with that of the bulk AuPd (1:1) alloy with an fcc crystal structure, being similar to AuPd alloy particles sputterdeposited in an IL of 1-butyl-3-methylimidazolium bis(trifluoromethanesulfonyl)amide (BMI-TFSA) reported in our previous paper. ${ }^{\mathbf{4 1}}$ The heat treatment of bare AuPd particles caused the narrowing of each diffraction peak due to the enlargement of the crystallite size with coalescence between nanoparticles, the degree being enhanced with an increase in the heating temperature. In contrast, the XRD patterns of

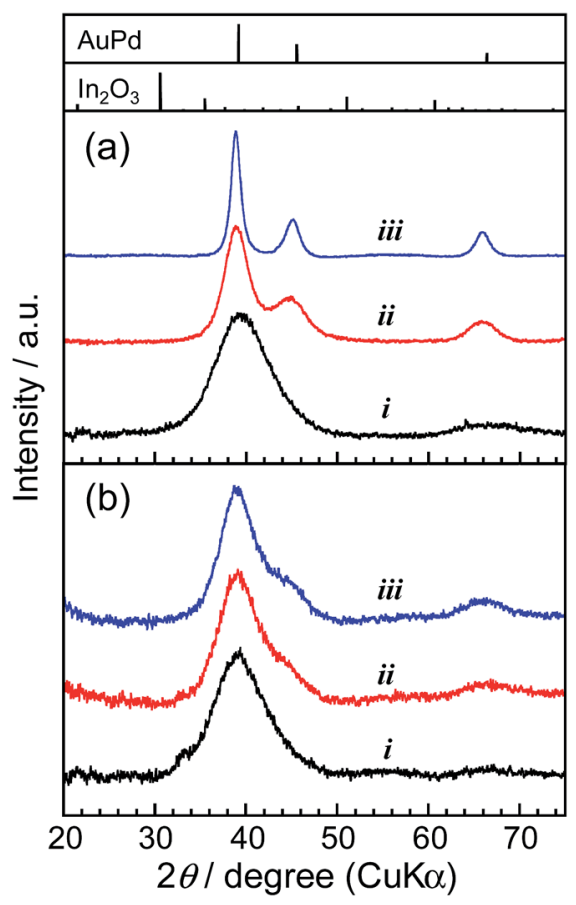

Fig. 5 XRD patterns of (a) bare AuPd particles and (b) AuPd a $\ln _{2} \mathrm{O}_{3}$ particles covered with a $0.79 \mathrm{~nm}$-thick $\mathrm{In}_{2} \mathrm{O}_{3}$ shell. The samples were as-prepared (i) and heat-treated at 100 (ii) and $200{ }^{\circ} \mathrm{C}$ for $30 \mathrm{~min}$ (iii). Standard diffraction patterns of fcc AuPd $(1: 1)$ alloy and cubic $\ln _{2} \mathrm{O}_{3}$ (PDF card\# 01-072-537 and 00-006-0416, respectively) are also shown.
AuPd@ $\operatorname{In}_{2} \mathrm{O}_{3}$ particles did not show any remarkable changes after heat treatment at 100 or $200{ }^{\circ} \mathrm{C}$, indicating that the $\operatorname{In}_{2} \mathrm{O}_{3}$ shell layer on AuPd cores prevented the coalescence of core particles. The HAADF-STEM measurements revealed that the amorphous $\mathrm{In}_{2} \mathrm{O}_{3}$ shell still covered the AuPd core even after the heat treatment of AuPd@ $\operatorname{In}_{2} \mathrm{O}_{3}$ with $250{ }^{\circ} \mathrm{C}$ (Fig. S3 $\dagger$ ). It is noteworthy that no diffraction peaks assigned to the $\operatorname{In}_{2} \mathrm{O}_{3}$ crystal were observed in Fig. 5b, being in good agreement with the formation of an amorphous shell layer on the surface of AuPd core particles as observed in HAADF-STEM images (Fig. 4 and $\mathrm{S} 3 \dagger$ ).

\section{Electrocatalytic activities of AuPd@In $\mathrm{O}_{3}$}

The electrocatalytic activity of AuPd nanoparticles has attracted intensive research interest for the development of highly efficient fuel cells. ${ }^{41,49}$ When AuPd@In ${ }_{2} \mathrm{O}_{3}$ core-shell particles are used as electrocatalysts, it is expected that the presence of a metal oxide shell layer and its thickness influence the activity of AuPd cores. In fact, it has been reported for core-shell-structured $\mathrm{SiO}_{2}$-coated CdS particles $\left(\mathrm{CdS} @ \mathrm{SiO}_{2}\right)^{50}$ that the increase in the $\mathrm{SiO}_{2}$ shell thickness significantly decreased the reaction rate of $\mathrm{CdS}$ cores for photocatalytic hydrogen evolution. Furthermore, the $\operatorname{In}_{2} \mathrm{O}_{3}$ shell can also be expected to enable an electron transfer between AuPd catalyst cores and a collecting electrode due to its semiconductor behaviour.

Nanoparticles dispersed in RTILs were immobilized on HOPG electrodes by heat treatment at 100 or $200{ }^{\circ} \mathrm{C}$. The AFM measurements (Fig. 6) revealed that bare AuPd and AuPd@ $\operatorname{In}_{2} \mathrm{O}_{3}$ particles prepared by 10 min-In sputtering (shell thickness: $0.79 \mathrm{~nm}$ ) were successfully immobilized on HOPG surfaces without large aggregate formation at $100{ }^{\circ} \mathrm{C}$. A similar (a)

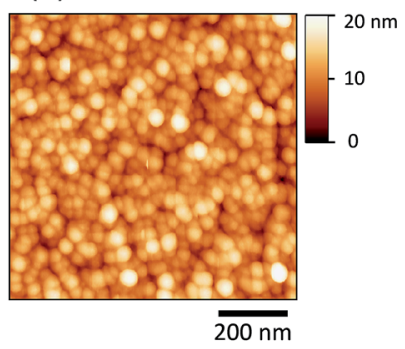

(c)

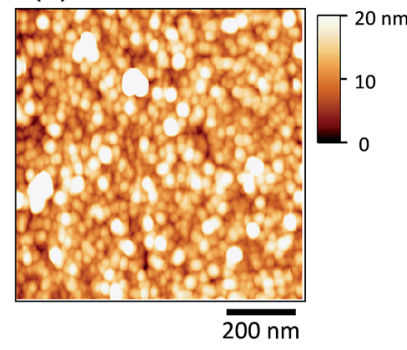

(b)

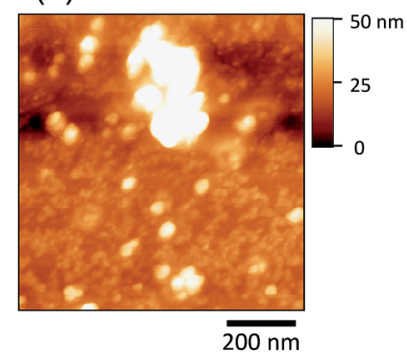

(d)

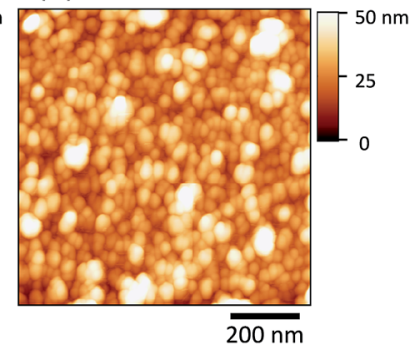

Fig. 6 AFM images of the HOPG surface modified with bare AuPd particles ( $a$ and b) or AuPd@ $\ln _{2} \mathrm{O}_{3}$ covered with a $0.79 \mathrm{~nm}$-thick $\ln _{2} \mathrm{O}_{3}$ shell ( $c$ and d). The immobilization temperature equalled 100 ( $a$ and $c$ ) or $200^{\circ} \mathrm{C}(\mathrm{b}$ and $\mathrm{d})$. 
uniform immobilization was observed for AuPd@ $\operatorname{In}_{2} \mathrm{O}_{3}$ (Fig. 6d) but not for bare AuPd particles (Fig. 6b) upon heat treatment at $200{ }^{\circ} \mathrm{C}$, the latter of which formed large aggregates.

Fig. 7a shows the cyclic voltammograms for ORR involving AuPd@In ${ }_{2} \mathrm{O}_{3}$ particles presenting different shell thicknesses and immobilized at $100{ }^{\circ} \mathrm{C}$. Bare AuPd particles showed an oxygen reduction peak at around $0.81 \mathrm{~V} v s$. RHE in the negative potential scan but no anodic current peak appeared in the positive potential scan, indicating that oxygen mainly underwent reduction to water on the AuPd surface ( $4 \mathrm{e}^{-}$reduction). At the AuPd@ $\operatorname{In}_{2} \mathrm{O}_{3}$ electrode, the peak potential slightly shifted to
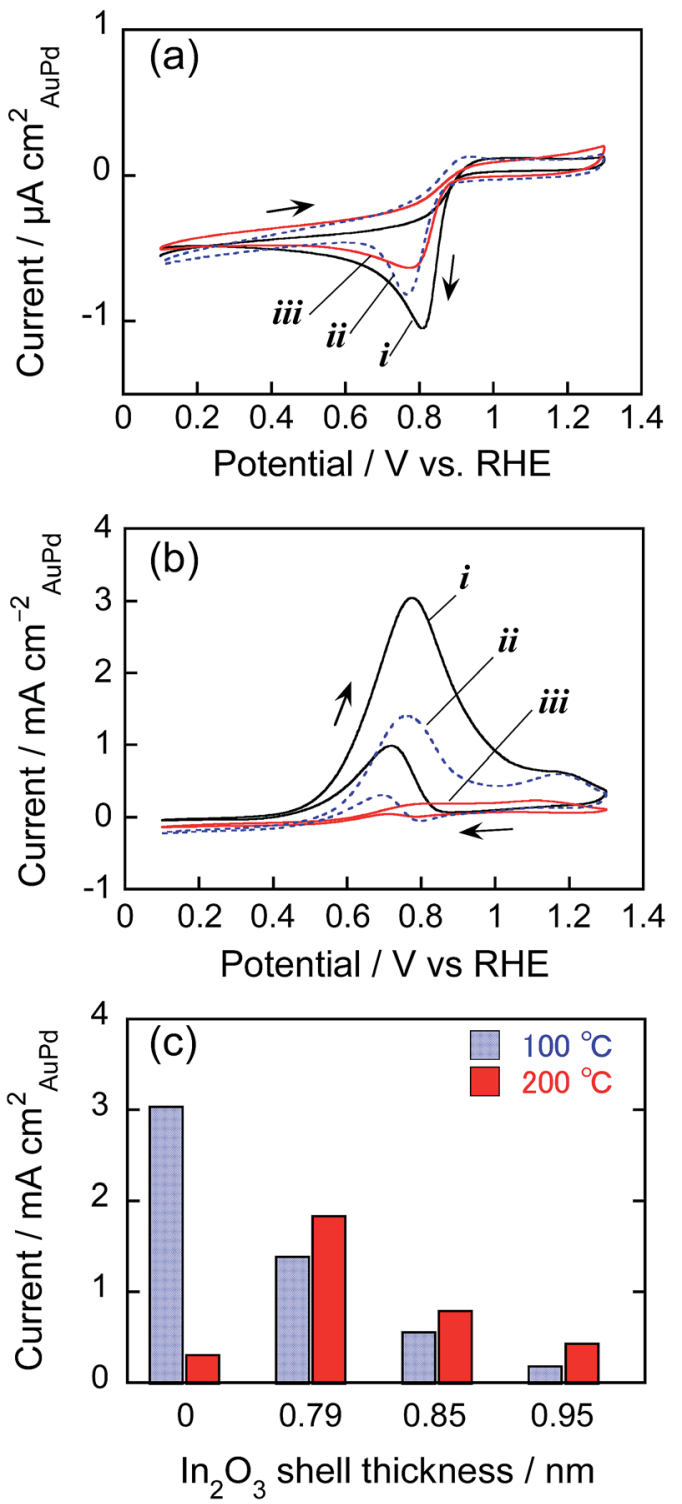

Fig. 7 ( $a$ and b) Cyclic voltammograms for (a) ORR in $\mathrm{O}_{2}$-saturated $0.50 \mathrm{~mol} \mathrm{dm}^{-3} \mathrm{KOH}$ aqueous solution and (b) ethanol oxidation in $0.50 \mathrm{~mol} \mathrm{dm}^{-3} \mathrm{KOH}$ aqueous solution containing $0.50 \mathrm{~mol} \mathrm{dm}^{-3}$ ethanol using HOPG electrodes modified with bare AuPd particles (i) and AuPd@ $\ln _{2} \mathrm{O}_{3}$ (ii and iii) at $100{ }^{\circ} \mathrm{C}$. The $\mathrm{In}_{2} \mathrm{O}_{3}$ shell thickness equalled 0.79 (ii) or $0.95 \mathrm{~nm}$ (iii). Potential sweep rate: $100 \mathrm{mV} \mathrm{s}^{-1}$. (c) Relationship between the peak current density of AuPdal $n_{2} \mathrm{O}_{3}$ modifed HOPG electrodes for ethanol oxidation and $\ln _{2} \mathrm{O}_{3}$ shell thickness. The immobilization temperature is shown in the figure. ca. $0.77 \mathrm{~V}$ vs. RHE and the peak current decreased with an increasing $\operatorname{In}_{2} \mathrm{O}_{3}$ shell thickness on the AuPd core. When the shell thickness was as thick as $0.95 \mathrm{~nm}$, the peak current amounted to $c a$. half of that obtained for bare AuPd particles. Interestingly, $\mathrm{In}_{2} \mathrm{O}_{3}$ hollow shell particles prepared by In metal sputter deposition exhibited negligible electrocatalytic activity for ORR (not shown). These results suggested that the amorphous $\mathrm{In}_{2} \mathrm{O}_{3}$ shell was probably porous enough to enable the diffusion of oxygen molecules from the bulk solution to the AuPd core surface acting as an ORR site inside the shell, and that the increase in $\operatorname{In}_{2} \mathrm{O}_{3}$ shell thickness lowered the diffusion rate of oxygen molecules.

Fig. 7b shows the cyclic voltammograms of AuPd particles for ethanol oxidation. Both bare AuPd and AuPd@ $\operatorname{In}_{2} \mathrm{O}_{3}$ particles exhibited an oxidation peak at around $0.8 \mathrm{~V} v s$., RHE, being in good agreement with previous reports, ${ }^{41}$ but the oxidation current decreased with increasing $\operatorname{In}_{2} \mathrm{O}_{3}$ shell thickness. Fig. 7c shows the change in peak current for ethanol oxidation in the positive potential scan as a function of $\operatorname{In}_{2} \mathrm{O}_{3}$ shell thickness. For AuPd@ $\mathrm{In}_{2} \mathrm{O}_{3}$ immobilized at $100{ }^{\circ} \mathrm{C}$, the peak current declined notably due to the presence of thicker $\operatorname{In}_{2} \mathrm{O}_{3}$ shells. The AuPd@ $\mathrm{In}_{2} \mathrm{O}_{3}$ covered with a $0.95 \mathrm{~nm}$ shell produced an oxidation peak current that equalled $c a$. one-tenth of that for bare AuPd particles. This difference in electrocatalytic activity between bare AuPd particles and AuPd@ $\operatorname{In}_{2} \mathrm{O}_{3}$ became more remarkable than that observed for ORR, where the decrease in electrocatalytic activity by $\mathrm{ca}$. half was caused by covering AuPd cores with a $0.95 \mathrm{~nm}$ shell (Fig. 7a). This was probably due to the difference in the diffusion rate of target molecules through the $\mathrm{In}_{2} \mathrm{O}_{3}$ shell layer: increasing $\operatorname{In}_{2} \mathrm{O}_{3}$ shell thickness more remarkably hindered the diffusion of ethanol molecules from the bulk solution to the reactive AuPd core surface rather than that of $\mathrm{O}_{2}$ ones. It is worth mentioning that $\mathrm{Au} @ \mathrm{In}_{2} \mathrm{O}_{3}$ particles could be similarly immobilized on HOPG electrodes at $100{ }^{\circ} \mathrm{C}$ without the formation of large aggregates and then exhibited a peak for ethanol oxidation in the cyclic voltammogram (Fig. S4a $\dagger$ ) at the potential of $c a .1 .15 \mathrm{~V} v s$. RHE, being similar to bare Au particles immobilized on HOPG at $100{ }^{\circ} \mathrm{C}$. However the peak current obtained with $\mathrm{Au} @ \mathrm{In}_{2} \mathrm{O}_{3}$ was much smaller than that of corresponding AuPd@ $\operatorname{In}_{2} \mathrm{O}_{3}$ with a $0.79 \mathrm{~nm}$ shell (Fig. 7b), because of lower electrocatalytic activity of Au particles than AuPd ones for ethanol oxidation. ${ }^{41}$

XPS measurements were carried out for AuPd-immobilized HOPG electrodes before and after cyclic voltammogram measurements in Fig. 7b with 100 cycles. As shown in Fig. S5, $\dagger$ as-prepared HOPG electrodes immobilized with bare AuPd or AuPd@ $\operatorname{In}_{2} \mathrm{O}_{3}$ particles exhibited the signals of $\mathrm{Au} 4 \mathrm{f}_{5 / 2}$ and $4 \mathrm{f}_{7 / 2}$ at binding energies of $86.8 \mathrm{eV}$ and $83.1 \mathrm{eV}$, respectively, which were in good agreement with those of corresponding signals for bare AuPd alloy particles reported in our previous paper. ${ }^{41}$ The positions of $\mathrm{Au}$ if signals were unchanged even after the electrochemical measurement, regardless of the presence of the $\mathrm{In}_{2} \mathrm{O}_{3}$ shell layer. Since the binding energy of $\mathrm{Au} 4 \mathrm{f}_{7 / 2}$ has been reported to decrease with a decrease in the fraction of $\mathrm{Au}$ in the AuPd alloy, ${ }^{51,52}$ it was indicated that dealloying of the AuPd alloy or segregation of $\mathrm{Au}$ in alloy particles did not occur when the 
particles of bare AuPd or AuPd@ $\operatorname{In}_{2} \mathrm{O}_{3}$ were used as electrocatalysts for ethanol oxidation.

The temperature adopted for the nanoparticle immobilization also significantly affected the electrocatalytic activity for ethanol oxidation as shown in Fig. 7c. With an increase in the immobilization temperature from 100 to $200{ }^{\circ} \mathrm{C}$, the peak current of ethanol oxidation for bare AuPd alloy particle electrodes remarkably decreased, accompanied with the positive shift of the peak potential from 0.8 to $c a$. $1.1 \mathrm{~V} v s$. RHE as shown in Fig. S4b. $\dagger$ Since bare AuPd alloy particles immobilized at $200{ }^{\circ} \mathrm{C}$ gave the oxidation peak at a potential similar to that of $\mathrm{Au}$ particle electrodes, ca. $1.15 \mathrm{~V}$ vs. RHE (Fig. S4a $\dagger$ ), it was suggested that the coalescence of alloy particles by the heat treatment at higher temperature (Fig. 6b) could produce a Aurich surface on bare AuPd alloy particles due to the partial segregation of $\mathrm{Au}$, resulting in the deterioration of ethanol oxidation activity of the AuPd alloy surface. In contrast, the electrocatalytic activity of $\mathrm{AuPd} @ \mathrm{In}_{2} \mathrm{O}_{3}$ in this reaction rose slightly when the immobilization temperature increased from 100 to $200{ }^{\circ} \mathrm{C}$, indicating that the heat resistance of AuPd@ $\operatorname{In}_{2} \mathrm{O}_{3}$ (Fig. 6 and $\mathrm{S} 3 \dagger$ ) resulted in maintaining their electrocatalytic activity after heat treatments at different temperatures.

\section{Durability of Pt@ $\operatorname{In}_{2} \mathrm{O}_{3}$-immobilized carbon catalysts for polymer electrolyte fuel cells}

Platinum is one of the metal catalysts exhibiting the highest electrocatalytic activity in fuel cells. Especially Pt-loaded carbon particles are widely utilized in polymer electrolyte fuel cells. The improvement of the durability of those catalysts is earnestly investigated as an important issue to achieve large-scale commercialization. The $\operatorname{In}_{2} \mathrm{O}_{3}$ surface coating of these particles into core-shell nanostructures $\left(\mathrm{Pt} @ \mathrm{In}_{2} \mathrm{O}_{3}\right)$, the structure of which prevents direct contact between $\mathrm{Pt}$ and carbon, is expected to increase the durability of Pt-loaded carbon materials under electrochemically oxidizing conditions.

TEM images of bare Pt particles and Pt@ $\mathrm{In}_{2} \mathrm{O}_{3}$ particles used for electrocatalysts are shown in Fig. 8. Spherical particles of 1.2 $\mathrm{nm}$ in average size were observed for bare Pt particles. The high resolution TEM images in the inset of Fig. 8a revealed that these Pt particles exhibited clear lattice fringes with a $0.23 \mathrm{~nm}$ interplanar spacing assignable to the Pt (111) lattice plane. On the other hand, Fig. 8b shows a TEM image of $\mathrm{Pt} @ \mathrm{In}_{2} \mathrm{O}_{3}$ particles which had a core-shell structure composed of a $1.2 \mathrm{~nm}$-diameter Pt particle core and a thin $\mathrm{In}_{2} \mathrm{O}_{3}$ shell layer exhibiting lighter contrast. The high-resolution HAADF-STEM image of these particles in Fig. 8c clearly indicates that Pt cores exhibiting a lattice fringe were covered with the amorphous $\operatorname{In}_{2} \mathrm{O}_{3}$ shell with a thickness less than ca. $0.8 \mathrm{~nm}$. The thickness of the $\operatorname{In}_{2} \mathrm{O}_{3}$ shell layer in $\mathrm{Pt} @ \mathrm{In}_{2} \mathrm{O}_{3}$ was less uniform than those observed for $\mathrm{Au} @ \mathrm{In}_{2} \mathrm{O}_{3}$ or AuPd@ $\mathrm{In}_{2} \mathrm{O}_{3}$ which showed dense $\mathrm{In}_{2} \mathrm{O}_{3}$ layers on metal cores (Fig. 2c and 4c), probably due to the short sputtering time of In, 2 min, used for the Pt@ $\operatorname{In}_{2} \mathrm{O}_{3}$ preparation. The elemental analysis of $\mathrm{Pt} @ \mathrm{In}_{2} \mathrm{O}_{3}$ revealed that the particles contained Pt and In with a Pt : In molar ratio of $1: 0.28$, being much smaller than that of $\mathrm{Au} @ \mathrm{In}_{2} \mathrm{O}_{3}$ prepared with In sputtering for $30 \mathrm{~min}, \mathrm{Au}: \mathrm{In}=1$ : 3.9. The thus-obtained Pt@ $\operatorname{In}_{2} \mathrm{O}_{3}$
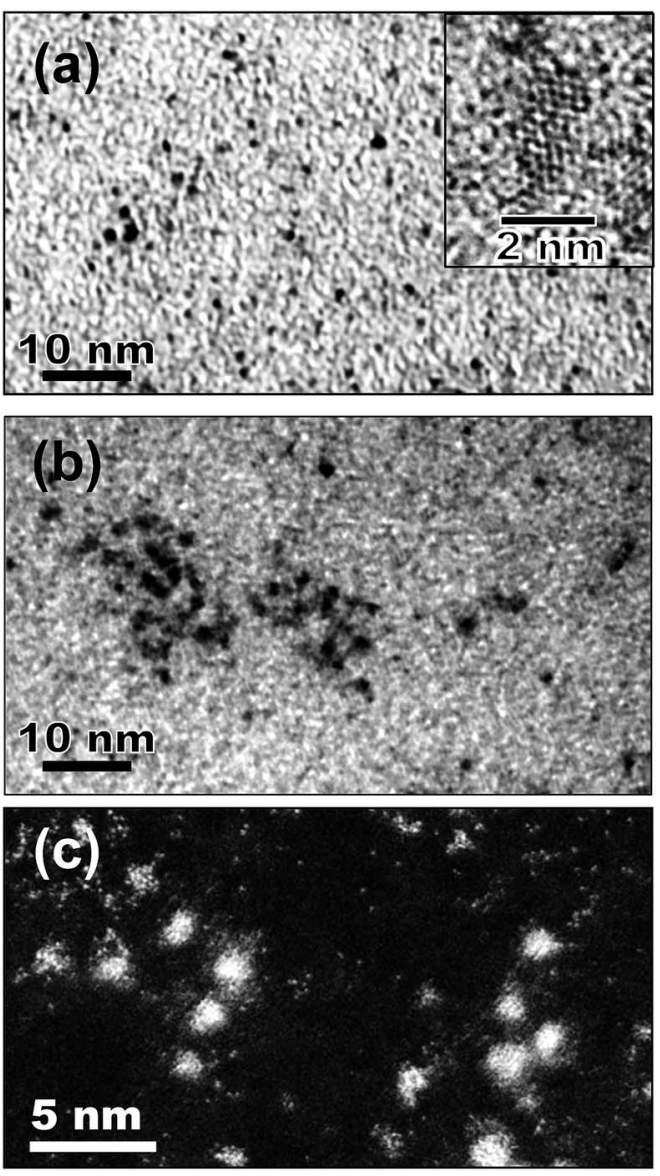

Fig. 8 (a) TEM images of as-prepared bare Pt particles sputterdeposited in BMI-BF4. The high resolution TEM image is shown in the inset. ( $b$ and $c$ ) Images of Pt@ $\ln { }_{2} \mathrm{O}_{3}$ prepared in BMI-BF4 obtained by conventional TEM (b) and HAADF-STEM (c).

particles were loaded in the carbon black powder so as to obtain the $\mathrm{Pt}$ content of $5 \mathrm{wt} \%$. The resulting catalyst powder was immobilized on a glassy carbon rotating-disk electrode using the ionomer Nafion ${ }^{\circledR}$. The durability of the $\mathrm{Pt} @ \mathrm{In}_{2} \mathrm{O}_{3} / \mathrm{C}$ catalyst was examined according to the FCCJ protocol ${ }^{\mathbf{4 4 , 4 5}}$ for the accelerated durability test of fuel cells.

Fig. 9a and b show the hydrodynamic voltammograms for the ORR of Pt/C and Pt@In $\mathrm{O}_{3} / \mathrm{C}$ catalysts, respectively, under the rotation of $1600 \mathrm{rpm}$ at a room temperature. In the case of the Pt/C catalyst, the cathodic currents due to ORR were gradually deteriorated during the durability test: with an increase in the number of potential step cycles, the onset potential of ORR became more negatively shifted. On the other hand, interestingly, the $\mathrm{Pt} @ \operatorname{In}_{2} \mathrm{O}_{3} / \mathrm{C}$ catalyst exhibited improvement of the catalytic activities at the first 4000 cycles, followed by some deterioration till 6000 cycles. To quantitatively evaluate the change in the ORR activity, the half-wave potential $\left(E_{1 / 2}\right)$, at which the cathodic current is one-half of the limiting current, was estimated from the voltammograms in Fig. 9a and b. Fig. 9c shows the relationship between $E_{1 / 2}$ and the number of potential step cycles. The $E_{1 / 2}$ obtained for Pt/C catalysts was rapidly negative-shifted by increasing the potential step cycle up to 5000 , whereas the $\mathrm{Pt} @ \mathrm{In}_{2} \mathrm{O}_{3} / \mathrm{C}$ catalyst gave roughly constant 

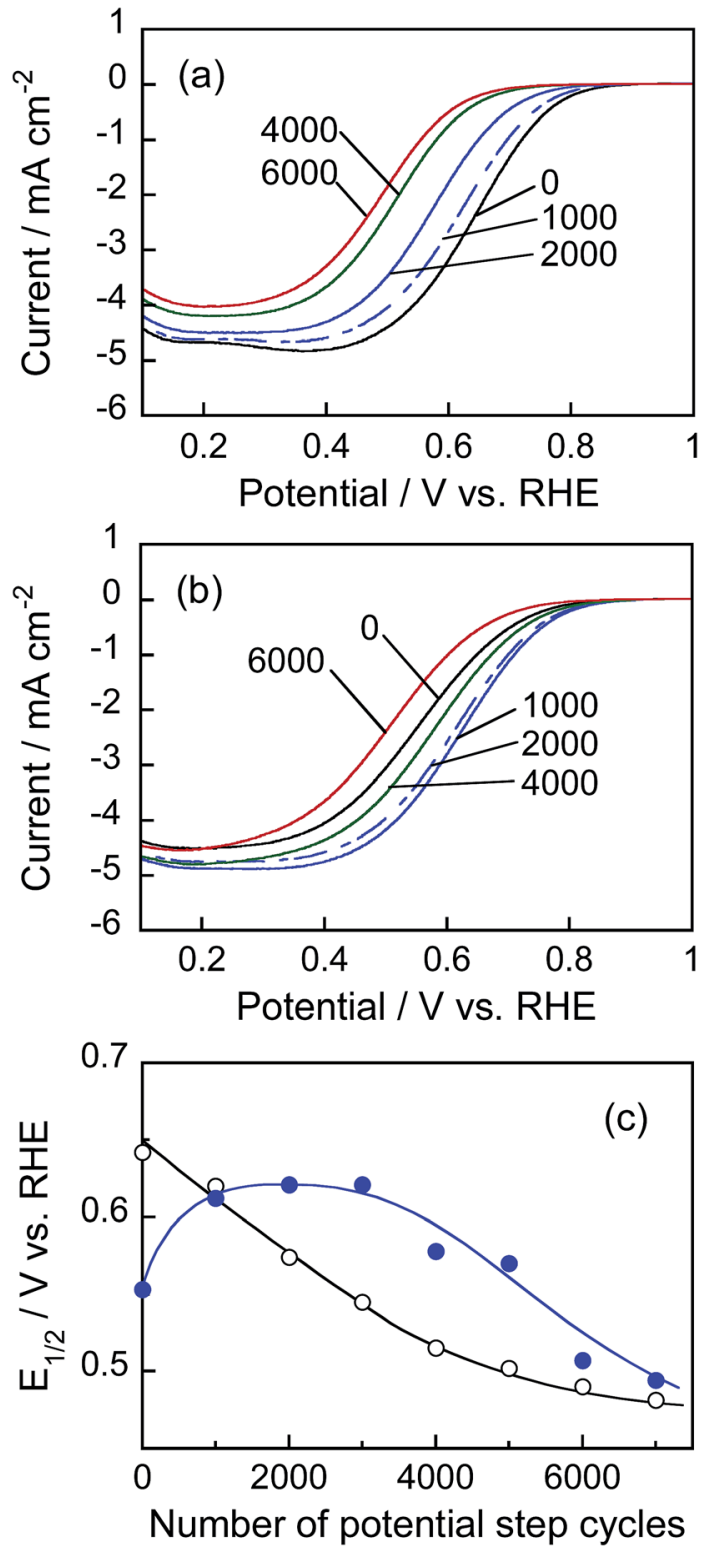

Fig. 9 (a and b) Hydrodynamic voltammograms for ORR in $\mathrm{O}_{2}$-saturated $0.1 \mathrm{~mol} \mathrm{dm} \mathrm{dm}^{-3} \mathrm{HClO}_{4}$ aqueous solution using rotating disc electrodes immobilized with $\mathrm{Pt} / \mathrm{C}$ (a) or Ptaln $\mathrm{O}_{3} / \mathrm{C}$ catalysts (b). Potential sweep rate: $10 \mathrm{mV} \mathrm{s}^{-1}$. The number of potential step cycles is indicated in the figure. (c) Plots of half-wave potential $\left(E_{1 / 2}\right)$ for ORR obtained with $\mathrm{Pt} / \mathrm{C}$ (open circles) and Ptaln $\mathrm{n}_{2} \mathrm{O}_{3} / \mathrm{C}$ catalysts (solid circles) as a function of the number of potential step cycles in the accelerated durability test.

$E_{1 / 2}$ within 3000 cycles, except for the positive shift of $E_{1 / 2}$ at the initial stage of the durability test. The negative shift of $E_{1 / 2}$ was also observed for the $\mathrm{Pt} @ \operatorname{In}_{2} \mathrm{O}_{3} / \mathrm{C}$ electrode when the potential cycles exceeded 3000. It is likely that the deterioration of the catalytic activities observed for the $\mathrm{Pt} / \mathrm{C}$ electrode was partially due to decrease in the surface of the Pt catalyst because the diffusion-limited current steadily decreased with potential cycling.

In order to find out information on Pt surface changes, the ECSA of Pt was determined using the hydrogen adsorption peak

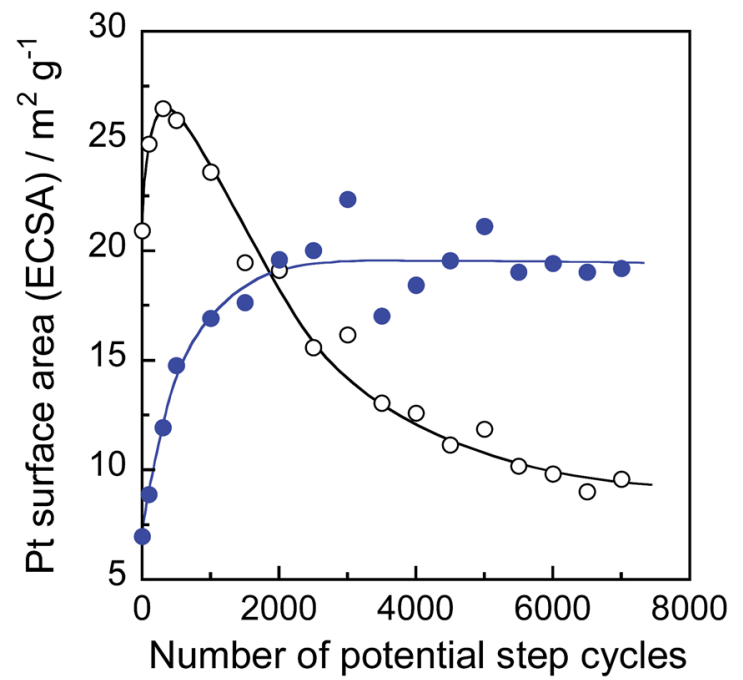

Fig. 10 ECSA changes of $\mathrm{Pt} / \mathrm{C}$ (open circles) and Ptal $\mathrm{n}_{2} \mathrm{O}_{3} / \mathrm{C}$ composites (solid circles) during the accelerated durability test of fuel cells.

in the cyclic voltammograms (Fig. S6 $\dagger$ ) and the charge required for hydrogen adsorption on unit platinum area $\left.\left(210 \mu \mathrm{C} \mathrm{cm}^{-2}\right)\right)^{45}$ Fig. 10 shows the changes in ECSA during potential cycle tests for Pt/C and Pt@ $\mathrm{In}_{2} \mathrm{O}_{3} / \mathrm{C}$. For the Pt/C catalyst, the ECSA initially increased with the rising cycle number up to 500 probably because of the removal of strongly absorbed ionic liquid species on the Pt surface. Meanwhile, the further potential cycling gradually deteriorated the ECSA. A similar behaviour has been widely reported previously, ${ }^{45,53-55}$ in which the decrease in ECSA was usually interpreted as the coalescence of loaded Pt nanoparticles into larger ones and/or the Pt particle detachment caused by the carbon support damage. In contrast, the $\operatorname{In}_{2} \mathrm{O}_{3}$ coating of Pt nanoparticles contributed to higher durability. The very small initial ECSA in Pt@ $\operatorname{In}_{2} \mathrm{O}_{3}$ may stem from the strong adsorption of ionic liquid species on $\mathrm{Pt} @ \mathrm{In}_{2} \mathrm{O}_{3}$. However, it rapidly increased when the number of cycles rose up to $c a .2000$ before becoming constant without any detectable deterioration up to 7000 cycles. These results strongly suggest that the ultrathin $\mathrm{In}_{2} \mathrm{O}_{3}$ shells covering the Pt cores effectively inhibited the deterioration of the $\mathrm{Pt} @ \mathrm{In}_{2} \mathrm{O}_{3} / \mathrm{C}$.

\section{Conclusions}

The coating of noble metal nanoparticles smaller than $c a .2 .5$ nm using an ultrathin metal oxide shell layer (thickness $<c a .1 .5$ $\mathrm{nm}$ ), which was difficult to be prepared by conventional chemical strategies such as sol-gel methods, was achieved by the RTIL/sequential metal sputter deposition. In this technique, the shell thickness was readily controlled by changing the sputtering time. Coating with a thin $\operatorname{In}_{2} \mathrm{O}_{3}$ shell increased the stability of noble metal cores without losing electronic conduction between noble metal cores and collecting electrodes. Metal core particles could work as electrocatalysts, probably because thin $\operatorname{In}_{2} \mathrm{O}_{3}$ shell layers might be porous for small target molecules enough to penetrate through the shell 
from bulk solution toward metal core surfaces on which the electrocatalytic reaction occurred. These features are attractive for the development of highly active electrocatalysts. Therefore though only preparation of noble metal particles surface-coated with a thin $\operatorname{In}_{2} \mathrm{O}_{3}$ shell is described in this paper, the sequential sputter deposition of different metals in RTILs is expected to contribute significantly to the exploitation of novel nanostructured materials that will be key components for nextgeneration energy-conversion devices, such as fuel cells, solar cells, or photocatalysts.

\section{Acknowledgements}

This work was partially supported by a Grant-in-Aid for a Funding Program for Next Generation World-Leading Researchers (NEXT Program) and Grant-in-Aid for Challenging Exploratory Research (no. 26620191) from the Japan Society for the Promotion of Science.

\section{Notes and references}

1 R. Narayanan and M. A. El-Sayed, Nano Lett., 2004, 4, 1343. 2 C. Burda, X. B. Chen, R. Narayanan and M. A. El-Sayed, Chem. Rev., 2005, 105, 1025.

3 N. Tian, Z. Y. Zhou, S. G. Sun, Y. Ding and Z. L. Wang, Science, 2007, 316, 732.

4 M. Crespo-Quesada, A. Yarulin, M. S. Jin, Y. N. Xia and L. Kiwi-Minsker, J. Am. Chem. Soc., 2011, 133, 12787.

5 V. R. Stamenkovic, B. S. Mun, M. Arenz, K. J. J. Mayrhofer, C. A. Lucas, G. F. Wang, P. N. Ross and N. M. Markovic, Nat. Mater., 2007, 6, 241.

6 M. K. Debe, Nature, 2012, 486, 43.

7 J. Kaspar, P. Fornasiero and N. Hickey, Catal. Today, 2003, 77, 419.

8 H. S. Gandhi, G. W. Graham and R. W. McCabe, J. Catal., 2003, 216, 433.

9 T. Torimoto, J. P. Reyes, K. Iwasaki, B. Pal, T. Shibayama, K. Sugawara, H. Takahashi and B. Ohtani, J. Am. Chem. Soc., 2003, 125, 316.

10 S. Ikeda, S. Ishino, T. Harada, N. Okamoto, T. Sakata, H. Mori, S. Kuwabata, T. Torimoto and M. Matsumura, Angew. Chem., Int. Ed., 2006, 45, 7063.

11 S. H. Joo, J. Y. Park, C. K. Tsung, Y. Yamada, P. D. Yang and G. A. Somorjai, Nat. Mater., 2009, 8, 126.

12 K. Maeda, N. Sakamoto, T. Ikeda, H. Ohtsuka, A. Xiong, D. Lu, M. Kanehara, T. Teranishi and K. Domen, Chem.Eur. J., 2010, 16, 7750.

13 N. Zhang, S. Q. Liu and Y. J. Xu, Nanoscale, 2012, 4, 2227.

14 Q. Zhang, I. Lee, J. B. Joo, F. Zaera and Y. D. Yin, Acc. Chem. Res., 2013, 46, 1816.

15 S. Q. Liu, N. Zhang and Y. J. Xu, Part. Part. Syst. Charact., 2014, 31, 540.

16 S. H. Liu and M. Y. Han, Chem.-Asian J., 2010, 5, 36.

17 F. Zaera, Chem. Soc. Rev., 2013, 42, 2746.

18 F. Caruso, Adv. Mater., 2001, 13, 11.

19 L. Wang, T. Sasaki, Y. Ebina, K. Kurashima and M. Watanabe, Chem. Mater., 2002, 14, 4827.
20 S. Srivastava and N. A. Kotov, Acc. Chem. Res., 2008, 41, 1831. 21 X. W. Lou, L. A. Archer and Z. C. Yang, Adv. Mater., 2008, 20, 3987.

22 H. T. Sun, X. Sun, T. Hu, M. P. Yu, F. Y. Lu and J. Lian, J. Phys. Chem. C, 2014, 118, 2263.

23 Y. D. Yin, R. M. Rioux, C. K. Erdonmez, S. Hughes, G. A. Somorjai and A. P. Alivisatos, Science, 2004, 304, 711.

24 K. Y. Niu, J. Park, H. M. Zheng and A. P. Aivisatos, Nano Lett., 2013, 13, 5715.

25 K. Richter, A. Birkner and A. V. Mudring, Angew. Chem., Int. Ed., 2010, 49, 2431.

26 K. Ueno, A. Inaba, Y. Sano, M. Kondoh and M. Watanabe, Chem. Commun., 2009, 3603.

27 M. Armand, F. Endres, D. R. MacFarlane, H. Ohno and B. Scrosati, Nat. Mater., 2009, 8, 621.

28 C. Vollmer, E. Redel, K. Abu-Shandi, R. Thomann, H. Manyar, C. Hardacre and C. Janiak, Chem.-Eur. J., 2010, 16, 3849.

29 M. Brettholle, O. Hofft, L. Klarhofer, S. Mathes, W. MausFriedrichs, S. Z. El Abedin, S. Krischok, J. Janek and F. Endres, Phys. Chem. Chem. Phys., 2010, 12, 1750.

30 J. Dupont and J. D. Scholten, Chem. Soc. Rev., 2010, 39, 1780. 31 S. Kuwabata, T. Tsuda and T. Torimoto, J. Phys. Chem. Lett., 2010, 1, 3177.

32 T. Torimoto, T. Tsuda, K. Okazaki and S. Kuwabata, Adv. Mater., 2010, 22, 1196.

33 J. D. Scholten, B. C. Leal and J. Dupont, ACS Catal., 2012, 2, 184.

34 T. Torimoto, K. Okazaki, T. Kiyama, K. Hirahara, N. Tanaka and S. Kuwabata, Appl. Phys. Lett., 2006, 89, 243117.

35 K. Okazaki, T. Kiyama, K. Hirahara, N. Tanaka, S. Kuwabata and T. Torimoto, Chem. Commun., 2008, 691.

36 Y. Oda, K. Hirano, K. Yoshii, S. Kuwabata, T. Torimoto and M. Miura, Chem. Lett., 2010, 39, 1069.

37 Y. Hatakeyama, S. Takahashi and K. Nishikawa, J. Phys. Chem. C, 2010, 114, 11098.

38 H. Wender, R. V. Goncalves, A. F. Feil, P. Migowski, F. S. Poletto, A. R. Pohlmann, J. Dupont and S. R. Teixeira, J. Phys. Chem. C, 2011, 115, 16362.

39 K. Yoshii, T. Tsuda, T. Arimura, A. Imanishi, T. Torimoto and S. Kuwabata, RSC Adv., 2012, 2, 8262.

40 S. Suzuki, T. Suzuki, Y. Tomita, M. Hirano, K. Okazaki, S. Kuwabata and T. Torimoto, CrystEngComm, 2012, 14, 4922.

41 M. Hirano, K. Enokida, K. Okazaki, S. Kuwabata, H. Yoshida and T. Torimoto, Phys. Chem. Chem. Phys., 2013, 15, 7286.

42 H. Wender, P. Migowski, A. F. Feil, S. R. Teixeira and J. Dupont, Coord. Chem. Rev., 2013, 257, 2468.

43 Y. W. Lee, M. Kim, Y. Kim, S. W. Kang, J. H. Lee and S. W. Han, J. Phys. Chem. C, 2010, 114, 7689.

44 Fuel Cell Commercialization Conference of Japan (FCCJ), Proposals of the development targets, research and development challenges and evaluations methods concerning PEFCs, http://fccj.jp/pdf/23_01_kt.pdf.

45 H. Yano, T. Akiyama, P. Bele, H. Uchida and M. Watanabe, Phys. Chem. Chem. Phys., 2010, 12, 3806. 
46 T. Suzuki, K. Okazaki, S. Suzuki, T. Shibayama, S. Kuwabata and T. Torimoto, Chem. Mater., 2010, 22, 5209.

47 B. Balamurugan, F. E. Kruis, S. M. Shivaprasad, O. Dmitrieva and H. Zahres, Appl. Phys. Lett., 2005, 86, 083102.

48 A. Monopoli, A. Afzal, C. di Franco, N. Ditaranto, N. Cioffi, A. Nacci, P. Cotugno and L. Torsi, J. Mol. Catal. A: Chem., 2014, 386, 101.

49 C. Bianchini and P. K. Shen, Chem. Rev., 2009, 109, 4183.

50 B. Pal, T. Torimoto, K. Okazaki and B. Ohtani, Chem. Commun., 2007, 483.
51 P. A. P. Nascente, S. G. C. Decastro, R. Landers and G. G. Kleiman, Phys. Rev. B: Condens. Matter Mater. Phys., 1991, 43, 4659.

52 S. Deki, K. Akamatsu, Y. Hatakenaka, M. Mizuhata and A. Kajinami, Nanostruct. Mater., 1999, 11, 59.

53 Y. Shao-Horn, W. C. Sheng, S. Chen, P. J. Ferreira, E. F. Holby and D. Morgan, Top. Catal., 2007, 46, 285.

54 K. C. Neyerlin, R. Srivastava, C. F. Yu and P. Strasser, J. Power Sources, 2009, 186, 261.

55 F. Hasche, M. Oezaslan and P. Strasser, Phys. Chem. Chem. Phys., 2010, 12, 15251. 